Oriental Insects, Vol. 40: 23-32, 2006.

\title{
A NEW SPECIES OF THE ANT GENUS DILOBOCONDYLA (HYMENOPTERA: FORMICIDAE) FROM INDIA, WITH NOTES ON ITS NESTING BEHAVIOUR
}

\author{
THRESIAMMA VARGHESE \\ Centre for Ecological Sciences, Indian Institute of Science, Bangalore 560 012, India \\ Email: thresi@ces.iisc.ernet.in
}

\begin{abstract}
A new species of Dilobocondyla, viz., D. bangalorica, sp. nov. is described from India. The worker, queen, male and larvae are described, along with notes on nesting behaviour. The genus Dilobocondyla is reviewed and 12 species are recognised: $D$. bangalorica, sp. nov., $D$. borneensis Wheeler, $D$. cataulacoidea (Stitz), D. chapmani Wheeler, D. didita (Walker), D. fouqueti Santschi, D. fulva Viehmeyer, D. karnyi Wheeler, D. rufobrunnea Wheeler, D. sebesiana Wheeler, D. selebensis (Emery), and D. simalurana Forel.
\end{abstract}

Key words: Dilobocondyla bangalorica, Myrmicinae, new species, India, nesting habits.

\section{Introduction}

Dilobocondyla Santschi (1910) with Atopomyrmex selebensis Emery (1898) as the type species, is a small genus of myrmicine ants belonging to the tribe Formicoxenini. It is known by 9 species and 2 subspecies from the Indo-Australian Region (Bolton, 1995). A new species, $D$. bangalorica is here described from India for the first time.

Early taxonomic works on the genus are by Walker (1859), Emery (1898), Stitz (1911), Forel (1915), Viehmeyer (1916), Wheeler (1916, 1924), Donisthorpe (1932, 1935), Taylor (1991), and Wang \& Wu (1992). Sunil et al. (1997) recorded the genus Dilobocondyla from Bangalore for the first time.

Wheeler (1924) wrote, "All the species of Dilobocondyla seem to be rare and very local ants and are therefore known mostly from single specimens. Like the species of the allied genus Podomyrma they nest as rather small colonies in the wood of living trees." In his paper he gave a key to the species and subspecies, of the genus based on workers and gynes, then known.

\section{Materials and Methods}

A few Dilobocondyla workers were collected on 15 July 2003 from Plumeria alba L. (Apocynaceae) tree from the Indian Institute of Science Campus, Bangalore $\left(13^{\circ} 01^{\prime} \mathrm{N}\right.$ $\left.77^{\circ} 34^{\prime} \mathrm{E}\right)$. A worker ant was traced to its nest, a cavity in a dead twig of $P$. alba tree, and later the whole colony was excavated and brought to the laboratory. A thorough survey to study the nesting habits of $D$. bangalorica, sp. nov. was made (May-July, 2004) in Cubbon park and Lalbagh Botanical gardens in Bangalore. A few more nests were found during this survey and three of them were collected on 7 July 2004, to study the colony structure of $D$. bangalorica. Various places in Masinagudi, (Western Ghats), Coorg and Mananthavady (Wayanad district, Kerala) were also surveyed, from May 2004-March 2005 , to understand the distribution of $D$. bangalorica, sp. nov. I could not notice the nest of $D$. bangalorica on any other trees and in any other places surveyed.

The holotype is deposited in the Insect Museum at the Centre for Ecological Sciences (CES), Indian Institute of Science, Bangalore. Paratypes will be deposited in the 
Zoological Survey of India, Kolkata, and in the British Museum (Natural History), London, UK.

All the specimens were examined using Wild stereo zoom microscope. All the drawings were made using the Wild Camera Lucida attached to the microscope. From the colony, which was collected on 15 July 2003 , 9 workers were randomly selected and were used for measurements.

The linear measurements and indices employed in this study are described below:
HL Head length: length of head from the posterior margin of the head to the anterior extremity of the clypeus.
HW Head width: maximum width of head, including the eyes.
EL Eye length: Length of compound eye measured in the same view as HL.
MFC Minimum frontal carina distance: minimum distance between the frontal carinae.
SL Scape length: length of the first antennal segment, excluding the radicle.
PRNW Pronotum width: width of the pronotum at the dorso-lateral margins.
PTL Petiole length: length of the petiole, measured in dorsal view.
PTW Petiole width: maximum width of the petiole in dorsal view.
PTH Petiole height: Maximum height of the petiole, measured in lateral view at right angles to petiole length.
PPTL Postpetiole length: Length of postpetiole measured in dorsal view.
PPTW Postpetiole width: width of postpetiole measured in dorsal view.
TL Maximum measurable length in lateral view.
CI Cephalic index: HW/HL $\times 100$
SI Scape index: SL/HW x 100
PTWI Petiole width index: PTW/PTL $x 100$
PPTWI Postpetiole width index: PPTW/PPTL x 100

\section{Dilobocondyla Santschi}

Dilobocondyla Santschi, 1910: 283-284. Type species: Atopomyrmex selebensis Emery, 1898: 234 (q.); by subsequent designation of Wheeler, 1911: 162.

Podomyrma (Mesomyrma) Stitz, 1911: 363. Type species: Podomyrma (Mesomyrma) cataulacoidea Stitz; by monotypy. Synonymy by Emery, 1912: 102.

Diagnosis: Head in frontal view with occipital corners acutely angulate to dentate; frontal carinae and antennal scrobes present and well developed; midpoint of anterior clypeal margin with an unpaired median seta; apical margin of mandibles with 6 teeth, mandibles elongate-triangular; palp formula 4, 3; antennae 12 segmented with 3 segmented club; compound eyes present and of moderate size. Mesosoma and petiolar nodes unarmed; petiole pedunculate with an anteriorly directed ventral tooth; postpetiole articulated on anterior surface of the first gastral segment. Gaster small and circular in dorsal view.

\section{Synonymic list of Dilobocondyla species}

The 12 species of Dilobocondyla, distributed in the Indo-Australian Region, are listed below:

1. Dilobocondyla bangalorica, sp. nov. India: Bangalore.

2. Dilobocondyla borneensis Wheeler, 1916: 12 (w.). Borneo. =braunsi Forel, 1912: 767 (synonymy by Bolton, 1982: 325)

3. Dilobocondyla cataulacoidea (Stitz), 1911: 364 (w.). New Guinea. $=$ concolor Viehmeyer, 1914: 40 (w.) (synonymy by Taylor 1991: 601)

4. Dilobocondyla chapmani Wheeler, 1924: 250 (w.). Philippines.

5. Dilobocondyla didita (Walker), 1859: 375 (w.). Sri Lanka. =escherichi (Forel), 1911: 223 (w.) (synonymy by Donisthorpe, 1932: 576). 
6. Dilobocondyla fouqueti Santschi, 1910: 283 (w.). Vietnam. $=$ lighti Wheeler, 1927: 6 (w.) (synonymy by Wang \& Wu, 1992: 562).

7. Dilobocondyla fulva Viehmeyer 1916: 127 (w. q.). Singapore. Raised to species by Taylor 1991: 601.

8. Dilobocondyla karnyi Wheeler, 1924: 249 (w.). Indonesia: Java.

9. Dilobocondyla rufobrunnea Wheeler, 1935: 43 (w. q. and m.), stat. rev. Philippines. Raised to species.

10. Dilobocondyla sebesiana Wheeler, 1924: 248 (q.). Indonesia: Sumatra.

11. Dilobocondyla selebensis (Emery), 1898: 234 (q.). Sulawesi.

12. Dilobocondyla simalurana Forel, 1915: 25 (w.), stat. rev. Sumatra. Raised to species.

\section{Dilobocondyla bangalorica, sp. nov.}

Holotype Worker (Plate 1, 1\&2): Head (Plate 1, 3) as long as broad (CI 100), slightly broader behind than in front, with almost straight cheeks, posterior corners dentate, directed outwards and broadly emarginated. Mandibles large and convex with 6 teeth (Plate 1, 4). Palp formula 4, 3. Clypeus almost flat, antero-medially emarginated, with a clear notch in the middle and sinuate at the corners with ridges. Frontal area distinct and triangular; frontal carinae long, sharp and continued to the posterior corners of the head, roughly 11 strong rugae between frontal carinae, antennal scrobes' deep and well defined. Antennae slender, 12 segmented with 3 segmented club; scape (SL 0.60, SI 66) slightly curved at the base, funiculus reaching about $1 / 3$ the length of the head. Eyes large (EL 0.20) and convex and almost in the middle of the sides. Thorax broad, not broader than head, pronotum broader than long (PRNW 0.65), its anterior lateral angles projecting outwards as tooth (Plate 1,5 ), pro-mesonotal suture indistinct dorsally, mesometanotal suture distinct and broadly constricted. Propodeum rounded and convex above with an abrupt small concave declivity (Plate 1,6). Metasternal angles lamellate and rounded. Petiole long (Plate 1, 7) (PTL 0.40, PTH 0.20) and arcuate in profile; 2.0x as long as broad (PTWI 50), with a strong antero-ventral, anteriorly directed tooth. Postpetiole higher, as long as broad (PPTWI 100) broader behind than in front, smaller than front and its sides rounded (Plate 1,8). Gaster circular in dorsal view rather convex above (Plate 2, $1 \&$ 2). Femora and tibiae incrassated (Plate 2, 3 \& 4).

Head, thorax, petiole and postpetiole strongly rugo-reticulate, with uniform meshes, the inter-rugal spaces shining, mandibles longitudinally striate, clypeus rather shining with a median and a pair of lateral carinae, base of gaster striate, rest closely punctate, coxae and femora lightly sculptured.

Body hairs sub erect, long, abundant and uniform (Plate 2, 1, 2, 5 \& 6).

Head, thorax, petiole and postpetiole ferruginous, scape of antennae, coxae, tips of legs and cheeks lighter, gaster brownish black.

Measurements: TL 3.93, HW 0.90, HL 0.90, EL 0.20, MFC 0.35, SL 0.60, PRNW 0.65, PTL 0.40, PTH 0.20, PTW 0.2, PPTL 0.30, PPTW 0.30, CI 100, SI 66, PTWI 50, PPTWI 100.

Worker measurements $(\mathrm{n}=9)$ : TL 3.40-4.05, HW 0.88-0.90, HL 0.88-0.95, EL 0.20, MFC 0.33-0.35, SL 0.55-0.60, PRNW 0.60-0.65, PTL 0.35-0.40, PTW 0.20, PTH 0.180.20, PPTL 0.28-0.30, PPTW 0.30, CI 95-100, SI 60-66, and PTWI 50-57, PPTWI 100101.

Queen: Similar to workers in colour (little darker) and sculpture. Head as long as broad, ocelli present, clypeus depressed in middle, deeply emarginated with well formed 
carinae. Antennae 12 segmented, with 3 segmented club; antennal scrobes well developed and running to the top of the head. Thorax gibbous, not broader than head; pro-mesonotal and meso-metanotal suture well developed. Pronotum wider than in workers, postpetiole longer and wider than in workers. Gaster circular in dorsal view. Femora and tibiae incrassated as in workers.

Measurements: TL 4.75; HW 1.05, HL 1.05, EL 0.25, MFC 0.40, SL 0.65, PRNW 0.85 , PTL 0.50, PTW 0.25, PTH 0.25, PPTL 0.43, PPTW 0.40, CI 100, SI 62, and PTWI 50, PPTWI 94.11.

Allotype Male (Plate 3, 1): Same data as the holotype and paratypes: Head distinctly broader than long (CI 123), broader medially with rounded cheeks, posteriorly weakly emarginated, posterior corners not evidently dentate as in workers. Mandibles well developed and somewhat convex (reduced when compared to that of workers) with distinct teeth. Clypeus nearly flat, its anterior border rounded and entire. Frontal area distinct, frontal carinae not very long, and not continued to the posterior corners of the head. Antennal scrobes well defined. Antennae 13 segmented, longer and stouter than in workers, but with no distinct club, scape remarkably short (SL 0.15 ), first funicular segment very small, broader than long, remaining funicular segments cylindrical and longer than broad. Eyes large and convex and almost in the middle of the sides of the head, ocelli large and distinct. Pronotum broader than head, its anterior lateral borders form angles, but not project as tooth as in workers, mesonotum convex and broader than pronotum. Wings transparent (Plate 3, $2 \&$ 3). Propodeum rounded and convex above with an abrupt small concave declivity. Petiole long (PTL 0.40), more than $2 \mathrm{x}$ as long as broad (PTWI 45) with a very weak ventral tooth. Gaster small, elongate, and convex above. Legs long and slender, femora clearly and tarsi slightly incrassated, less incrassated than in workers.

Head, thorax and petiole deeply sculptured, postpetiole and gaster smooth, mandibles rather smooth, clypeus longitudinally striate, base of gaster not striate as in workers, coxae and femora smooth and shining.

Body hairs long, suberect and sparse.

Black, head, thorax and petiole darker, gaster posteriorly brownish black, mandibles, antennae and legs pale white, coxae, femora and tibiae with tinge of brown; wings whitish with colourless veins.

Measurements: TL 3.40; HW 0.80, HL 0.65, EL 0.30, MFC 0.18, SL 0.15, PRNW 0.65 , PTL 0.40, PTW 0.18, PTH 0.20, PPTL 0.30, PPTW 0.25, CI 123, SI 19, PTWI 45, PPTWI 83.

Male genitalia as in figures 4, 5, 6 and 7 in Plate 3. It consists of a pair of well developed parameres, a pair of volsella and the median aedeagus. Anterior margin of hypopygium biconcave, with a prominent median rounded lobe, anterior lateral lobes prominent and rounded, sides slightly concave, posterior border more or less rounded and hairy; outer border of paramere convex, anteriorly rounded, inside concave, and medially slightly constricted; volsella well developed, volsella consists of cuspis and digitus, cuspis of volsella projects out from parameres; aedeagus narrow, broader in the middle, tapering anteriorly with a distinct pointed tip.

Holotype Worker, INDIA: Karnataka: Bangalore $\left(13^{\circ} 01^{\prime} \mathrm{N} 77^{\circ} 34^{\prime} \mathrm{E}\right)$ : Malleswaram: Indian Institute of Science Campus: 15.vii.2003, Coll. Thresiamma Varghese (collected from a nest in a cavity of living Plumeria alba tree) (CES). 
Paratypes: 91 workers, same data as holotype. INDIA: Karnataka: Bangalore: Jubilee Garden, $13^{\circ} 01^{\prime} \mathrm{N} 77^{\circ} 34^{\prime} \mathrm{E}$. Paratypes are deposited in the Insect Museum at the Centre for Ecological Sciences (CES), Indian Institute of Science, Bangalore. 2 Paratypes each will be deposited at the Museum of the Zoological Survey of India, Kolkatta (India), and at the British Museum of Natural History, London.

Non type specimens: INDIA: 5 workers, Karnataka: Bangalore $\left(13^{\circ} 01^{\prime} \mathrm{N} 77^{\circ} 34^{\prime} \mathrm{E}\right)$ : Malleswaram: Indian Institute of Science Campus: 20.ii.1997, Coll. M. Sunil Kumar \& K.T. Sree Hari. Karnataka: Bangalore (1301' N $\left.77^{\circ} 34^{\prime} \mathrm{E}\right)$ : Malleswaram: Indian Institute of Science Campus: 14 workers, 14 males, 5 alates, 07.vii.2004, Coll. Thresiamma Varghese. Karnataka: Bangalore ( $\left.13^{\circ} 01^{\prime} \mathrm{N} 77^{\circ} 34^{\prime} \mathrm{E}\right)$ : Cubbon park, 1 queen, 43 workers, 14 males, 31 alates, 07.vii.2004, Coll. Thresiamma Varghese. Same locality, 22 workers, 1 male, 13 alates, 07.vii.2004, Coll. Thresiamma Varghese.

Comparison: Dilobocondyla bangalorica keys to couplet 8 in Wheeler (1924). It comes closest to D. cataulacoidea in having (1) an average worker size above $3.25 \mathrm{~mm}$, (2) frontal carinae sharp, continuing to the posterior corners of the head, (3) similar body colour, (4) distinct meso-metanotal constriction, and (5) pronotum broader than long. $D$. bangalorica, however, is distinguished from $D$. cataulacoidea by the following characters: Smaller worker size, (D. bangalorica worker 3.93, vs $D$. cataulacoidea 4.50$)$, head width less than 1.00 (HW 1.03 in D. cataulacoidea), gaster striate only at base and brownish black (gaster longitudinally striate and black in $D$. cataulacoidea), mandibles with 6 teeth (5 teeth in D. cataulacoidea), and head as long as broad (CI 100, except one worker in D. bangalorica (head longer than broad in D. cataulacoidea).

D. bangalorica also differs from other known species by having a small worker size (3.93), by smaller queen size (4.75), having the thorax and pedicel sculptured, by its coloration, having 6 well defined mandibular teeth, and by having less rugosities between frontal carinae.

Etymology: The species is named after its type locality, Bangalore.

Distribution and biology: Dilobocondyla bangalorica was found nesting in a cavity of live Plumeria alba L. tree at the Indian Institute of Science Campus (Plate 4, 1). A single colony contained 1 queen, 91 workers, 15 males, 15 eggs, 10 pupae and 127 larvae at different developmental stages. The nest was shallow and wide (Plate 4, 2, $3 \& 4$ ). The workers forage individually on tree trunks and among foliage (Plate $4,5 \& 6$ ). When disturbed, they hide in deep grooves on tree trunk. Eggs are small (Plate 4, 7) and roughly oval. Larvae are elongate cylindrical with segmented body (Plate 4,8 ). They have a well formed neck, posteriorly little robust and rounded.

A comprehensive survey was made (May 2004- March 2005) in and around Bangalore, Masinagudi (Western Ghats), Coorg and in Mananthavady district of Kerala state to study the distribution and nesting behaviour of $D$. bangalorica. I saw 5 more nests of $D$. bangalorica on live Plumeria tree, two at the Cubbon Park, and one at the Indian Institute of Science campus, Bangalore respectively.

One nest of $D$. bangalorica was collected from $P$. alba tree, at the Indian Institute of Science Campus on 7 July 2004. It contained 14 workers, 14 males, 5 alates, 2 eggs, 34 larvae and 16 pupae. Either I failed to get the queen or that was an orphaned colony.

On the same day (7 July 2004), two nests of $D$. bangalorica from $P$. rubra were collected from the Cubbon park, and contained 1 queen, 43 workers, 31 alates, 14 males, 13 eggs, 58 larvae, 23 pupae, and 22 workers, 1 male, 13 alates, 1 egg, 26 larvae and 13 pu- 
pae respectively. D. bangalorica prefers to inhabit the holes on dead twigs of 2 species of Plumeria tree, P. alba L., and P. rubra L.

\section{Acknowledgments}

This work was supported by the Ministry of Environment and Forests, Government of India. I express my profound sense of gratitude to my teacher, Prof. Raghavendra Gadagkar, for his constant encouragement and support throughout my study. Prof. R. Gadagkar, Prof. T. C. Narendran, and Mrs. Swarnalatha Chandran kindly reviewed the manuscript. I thank Dr. Sam Philip for helping with the SEM pictures, Mr. Milind Kolatkar for technical assistance and Mr. Ponnanna and Ganesh for field assistance.

\section{References}

BOLTON, B., 1982. Afrotropical species of the Myrmicine ant genera Cardiocondyla, Leptothorax, Melissotarsus, Messor and Cataulacus. Bulletin of the British Museum (Natural History) (Entomology), 45: $307-370$.

BOLTON, B., 1995. A new general catalogue of the Ants of the World. Harvard University Press, Cambridge, Massachusetts, London, 504 pages.

DONISTHORPE, H., 1932. On the Identity of some ants from Ceylon described by F. Walker. Annals and Magazine of Natural History, (10) 9: 574-576.

DONISTHORPE, H., 1935. The ants of Christmas Island. Annals and Magazine of Natural History, (10) 15: 629-635.

EMERY, C., 1898. Descrizioni di formiche nuove malesi e australiane; note sinonimiche. Rendiconto delle Sessioni della R. Accademia delle Scienze dell'Instituto di Bologna (N.S.), 2: 231-245.

EMERY, C., 1912. Etudes sur les Myrmicinae. Annales de la Société Entomologique de Belgique, 56: 94105.

FOREL, A., 1911. Ameisen aus Ceylon, gesammelt von Prof. K Escherich (einige von Prof. E. Bugnion). In Escherich, K. Termitenleben auf Ceylon, 213-228.

FOREL, A., 1912. Descriptions provisoires de genres, sous-genres et espèces de formicides des Indes orientales. Revue Suisse de Zoologie, 20: 761- 774.

FOREL, A., 1915. Fauna Simalurensis. Hymenoptera Aculeata, Fam. Formicidae. Tijdschrift voor Entomologie, 58: 22-43.

SANTSCHI, F., 1910. Deux nouvelles fourmis du Tonkin. Naturaliste. 2 (32): 283-284.

STITZ, H., 1911. Australische Ameisen. (Neu-Guinea und Salomons-Inseln, Festland, Neu-Seeland). Sitzungsberichte der Gesellschaft Naturfor-schender Freunde zu Berlin, 351-381.

SUNIL KUMAR, M., SRIHARI, K. T., NAIR, P., VARGHESE, T., \& GADAGKAR, R., 1997. Ant species richness at selected localities of Bangalore, Insect Environment, 3: 3-5.

TAYLOR, R. W., 1991. Nomenclature and distribution of some Australasian ants of the Myrmicinae. Memoirs of the Queensland Museum, 30: 599-614.

VIEHMEYER, H., 1914. Neue und unvollständig bekannte Ameisen der alten Welt. Archiv für Naturgeschichte, 79: 24-60.

VIEHMEYER, H., 1916. Ameisen von Singapore. Beobachtet und gesammelt von H. Overbeck. Archiv für Naturgeschichte, 81: 108-168.

WALKER, F., 1859. Characters of some apparently undescribed Ceylon Insects. Annals and Magazine of Natural History, (3) 4: 370-376.

WANG, C., \& WU, J., 1992. Ants of the Jianfengling forest region in Hainan Province. Scientia Silvae Sinicae, 28: 561-564

WHEELER, W. M., 1911. A list of the type species of the genera and subgenera of Formicidae. Annals of the New York Academy of Sciences, 21: 157-175.

WHEELER, W. M., 1916. Four new and interesting ants from the mountains of Borneo and Luzon. Proceedings of the New England Zoological Club, 6: 9-18.

WHEELER, W. M., 1924. Ants of Krakatau and other Islands in the Sunda Straight. Treubia, 5: 239-258.

WHEELER, W. M., 1927. Chinese ants collected by Professor S. F. Light and Professor N. Gist Gee. American Museum Novitates, 255: 1-12.

WHEELER, W. M., 1935. New ants from the Philippines. Psyche, 42: 38-52. 

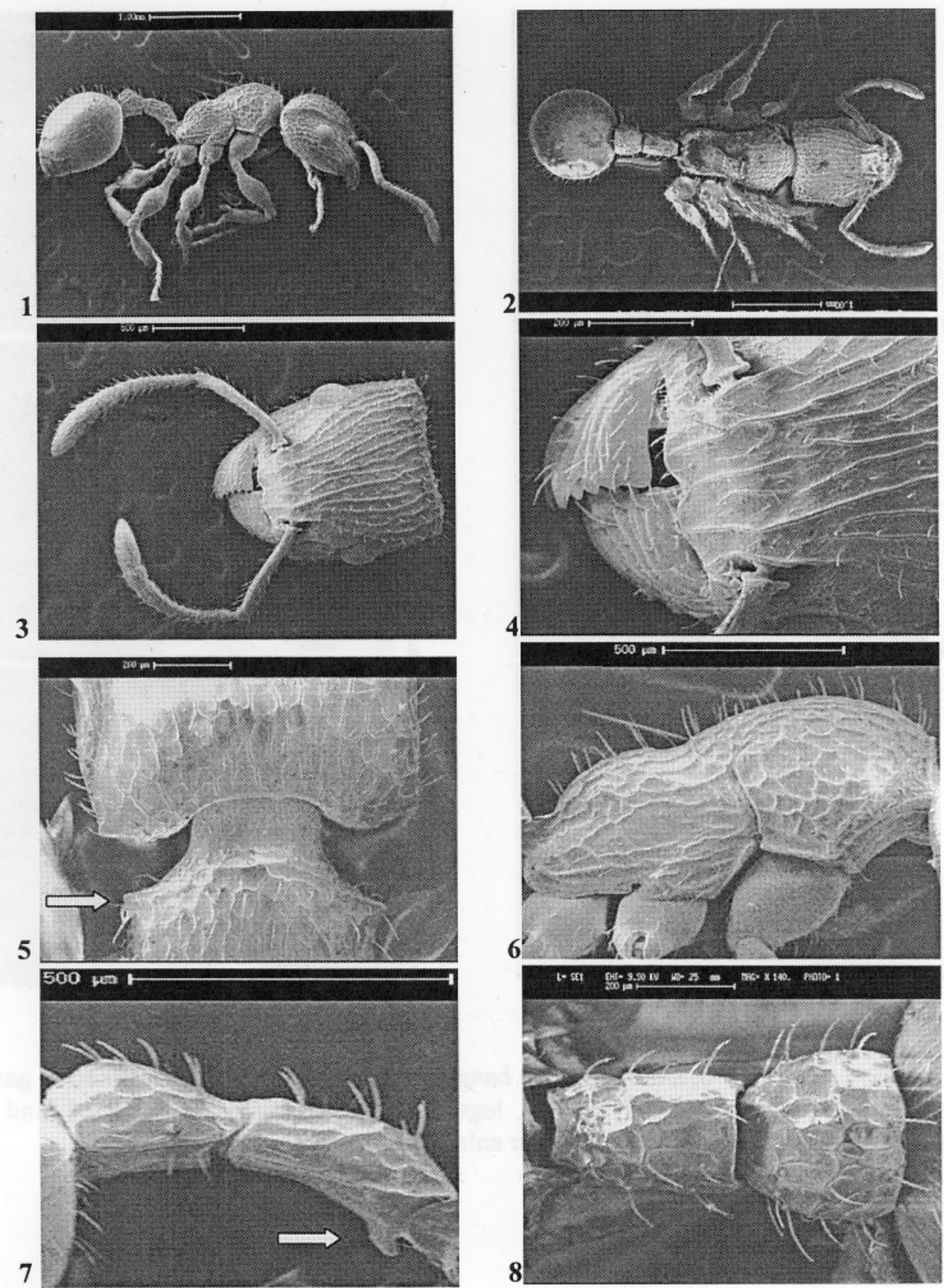

Plate 1. Figures 1-8, Dilobocondyla bangalorica, sp. nov., paratype worker: 1, profile; lateral view 2 , dorsal view 3 , head; frontal view; 4 , mandibles; 5 , antero-lateral corners of pronotum showing pronotal teeth; 6 , alitrunk, lateral view; 7 , petiole, lateral view; 8 , petiole and post petiole, dorsal view. 

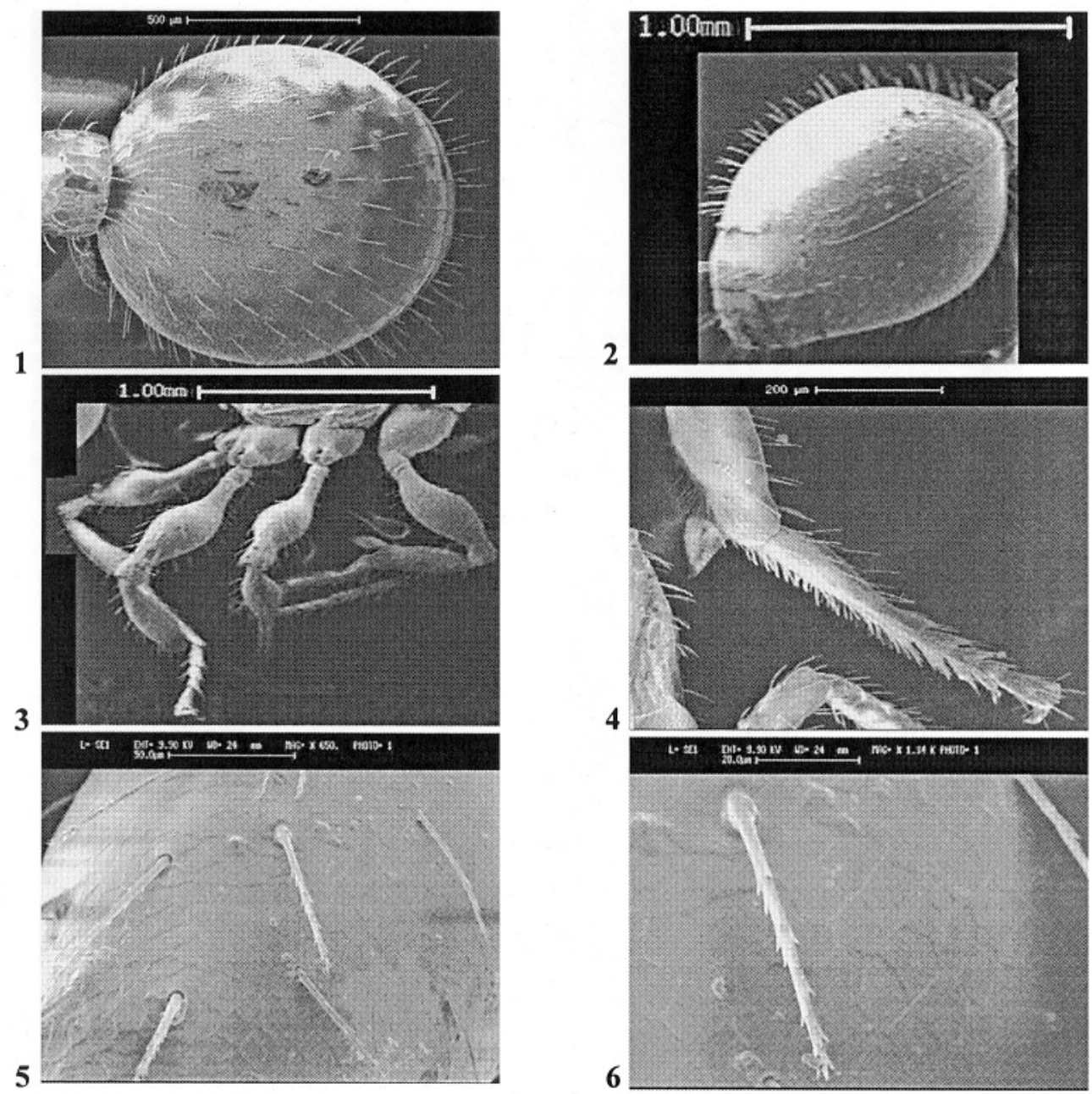

Plate 2. Figures 1-6, Dilobocondyla bangalorica, sp. nov., paratype worker: 1, gaster, dorsal view; 2, gaster, lateral view; 3 , legs; 4 , tarsus enlarged; 5 , femur of hind leg enlarged to show setae; 6 , setae on femur enlarged. 


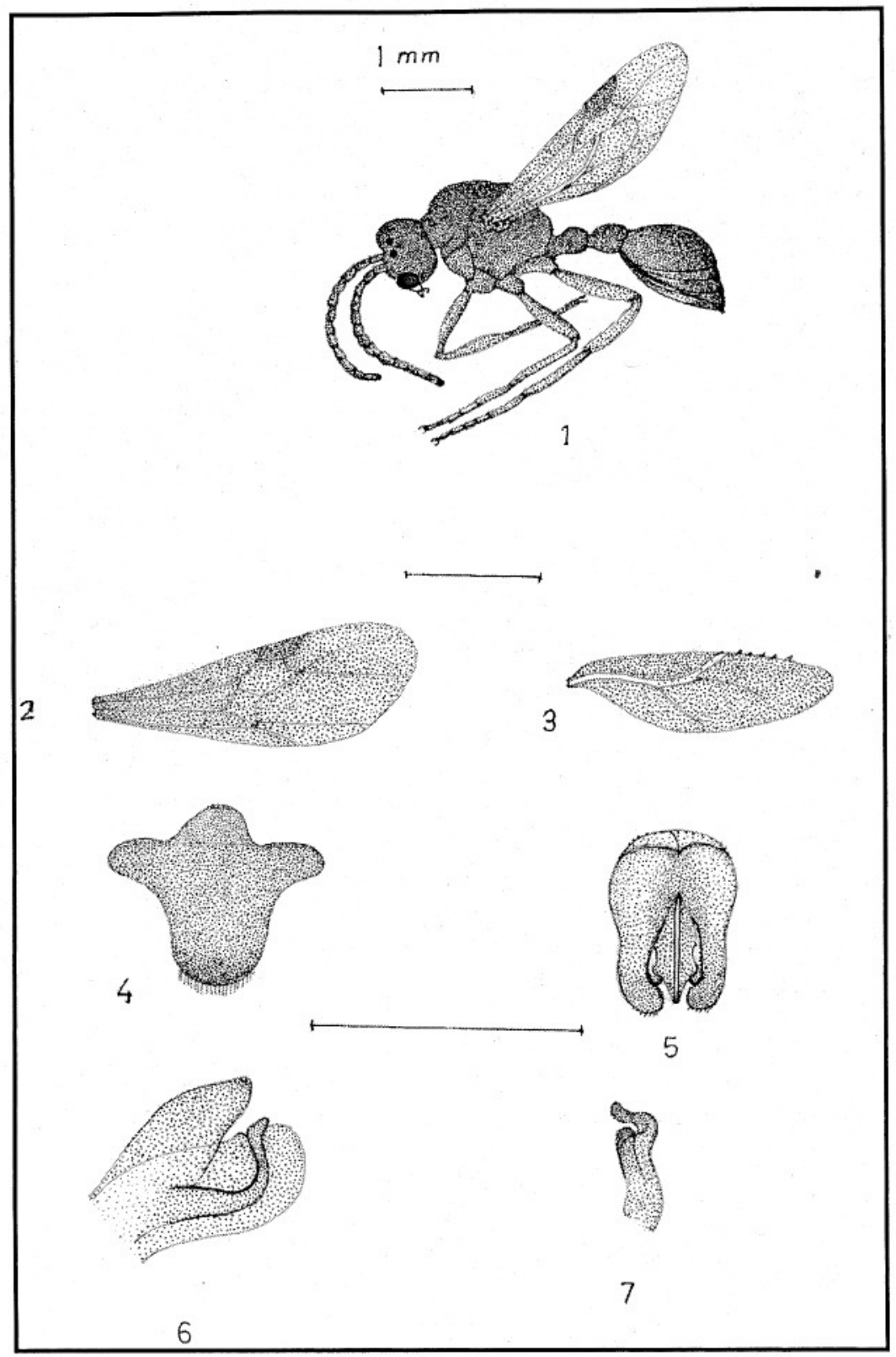

Plate 3. Figures 1-7, Dilobocondyla bangalorica, sp. nov., Male: 1, profile, lateral view; 2 , fore wing; 3 , hind wing; 4 , hypopygium; 5 , genitalia, dorsal view; 6 , genitalia, inner view showing volsella and aedeagus; 7 , volsella showing cuspis and digitus. 

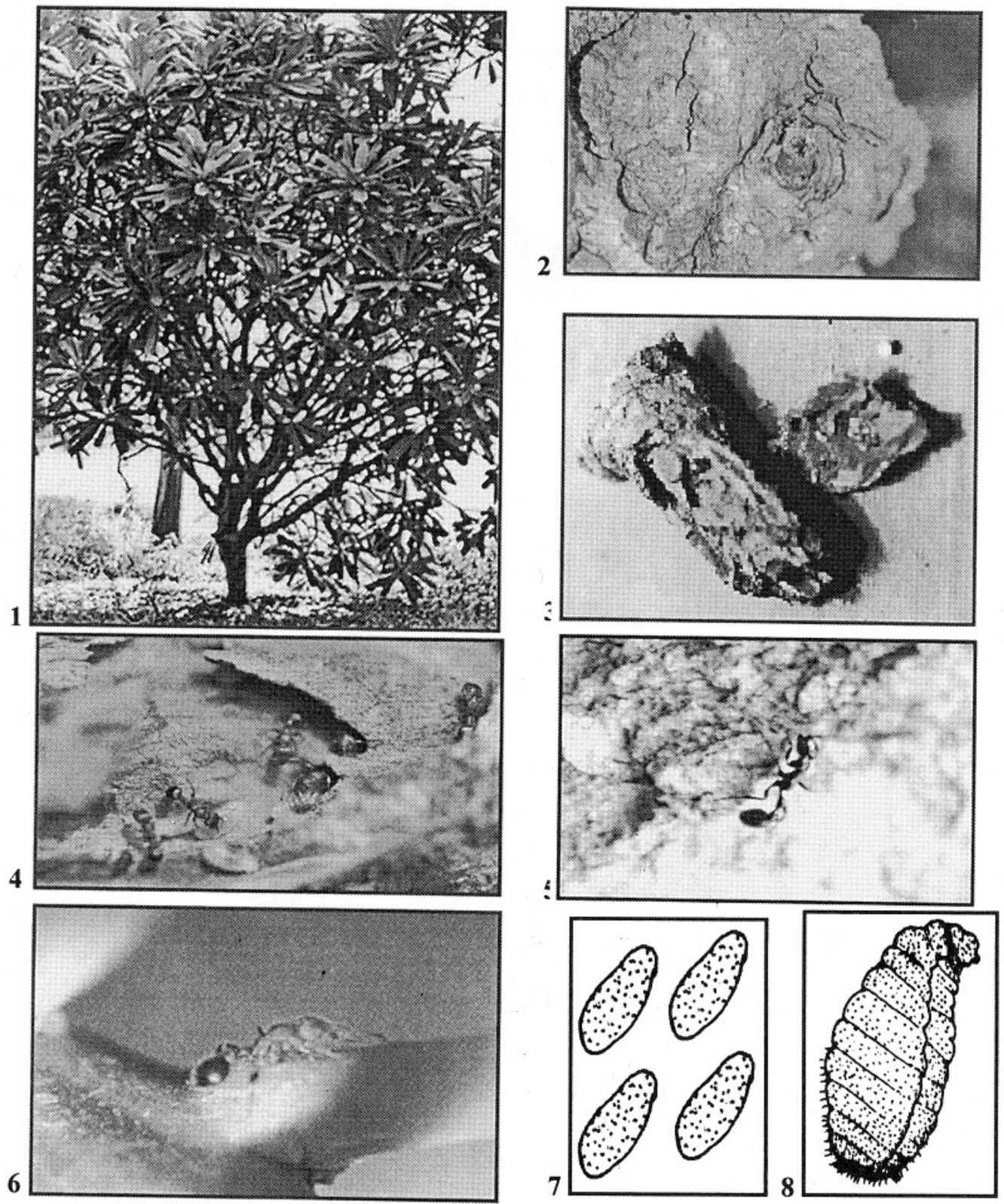

Plate 4. Figures 1-8. 1, host plant, Plumeria alba L.; 2, nest on Plumeria alba hole; 3, 4, nest opened; 5, Dilobocondyla bangalorica, sp. nov. workers foraging on Plumeria alba trunk; 6, D. bangalorica, sp. nov. forager among foliage of Plumeria alba trunk; 7, eggs; 8 , larva, lateral view. 